\title{
Theoretical modelling of Staphylococcus aureus growth in a cooked meat product kept at ambient temperature using temperature profiles of selected Mexican cities
}

\author{
Modelagem teórica de crescimento de Staphylococcus aureus em um produto à base de carne \\ cozida deixada à temperatura ambiente, usando perfis de temperatura de cidades do México
}

\section{Rosa BAEZA ${ }^{1}$, Cristina ROSSLER ${ }^{1,2}$, Diana MIELNICKI ${ }^{1,2}$, María Clara ZAMORA $^{1,3 *}$, Jorge CHIRIFE ${ }^{1}$}

\begin{abstract}
A theoretical model is used to predict the growth of Staphylococcus aureus in a pasteurized meat product kept at ambient temperatures for several hours. For this purpose, the temperature profiles of some cities of Mexico were combined with literature data on the kinetics of $S$. aureus growth. As shown by theoretical predictions, if the food is kept at ambient temperature, the average daily temperature may not give accurate predictions.
\end{abstract}

Keywords: predictive microbiology; cooked meat; generation time.

\section{Resumo}

Um modelo teórico é utilizado para prever o crescimento de Staphylococcus aureus em um produto à base de carne (pasteurizado) deixado por várias horas à temperatura ambiente. Para isso, perfis de temperatura de algumas cidades do México foram combinados com resultados de literatura sobre a cinética de crescimento de $S$. aureus. Como demonstrado por previsões teóricas, se o alimento é deixado à temperatura ambiente, a utilização da média diária da temperatura pode não dar previsões exatas.

Palavras-chave: microbiologia preditiva; carnes cozidas; tempo de geração.

\section{Introduction}

Staphylococcus aureus is a bacterium with strains that are capable of producing a highly heat-stable toxin that causes illnesses in humans. Intoxication is caused by ingesting enterotoxins produced in food by $S$. aureus usually because the food has been kept at ambient temperature (WALLS; SCOTT, 1997). Foods that require considerable handling during preparation and that are kept without refrigeration are usually implicated in staphylococcal food poisoning. This bacterium is able to grow in a wide range of temperatures $\left(7-48^{\circ} \mathrm{C}\right)$ with optimum growth at $35-37^{\circ} \mathrm{C}$, a range which may be frequent in warm climates.

Many foods are often prepared under unsanitary conditions and stored for long periods at ambient temperature before being sold (for example street foods or ready-to-eat foods). Thus, the time lapse between food preparation and consumption is an important factor to consider in terms of hazard. For example, street vendors cook in the morning and then store it at ambient temperatures for the rest of the day (MENSAH et al., 2002; CABALLERO TORRES et al., 1998). Daily temperature is never constant, and contaminated food products undergo a changing temperature environment. Therefore, a constant temperature prediction for bacterial growth may not be accurate. Risk assessments studies of food borne bacterial pathogens are usually performed at a constant temperature which mimics some average environmental temperature. However, this does not reflect adequately the actual temperature profile to which the food is exposed in a given time period of the day.

It is the purpose of the present paper to predict the extent of $S$. aureus growth which would occur when a cooked meat product is kept at ambient temperature for several hours but taking into account the changing environmental temperatures in warm climates (diurnal time). Temperature data corresponding to selected Mexican cities were used for calculations. Baeza et al. (2007) recently reported a similar analysis for S. aureus carried out in the same kind of cooked meat but exposed to environmental (ambient) fluctuating temperatures corresponding to selected warm cities of Argentina.

\section{Materials and methods}

\subsection{Analysis of data}

\section{Environmental (ambient) temperatures}

Data were obtained from the automatic weather stations of the National Meteorological Service/SMN of the National Water Commission, Mexico. Table 1 shows the geographical location of the selected Mexican cities, namely Iguala, Mérida, Palenque,

Recebido para publicação em 10/7/2007

Aceito para publicação em 28/10/2008 (002670)

${ }^{1}$ Facultad de Ciencias Agrarias, Pontificia Universidad Católica Argentina - UCA, Cap. Gral. Ramón Freire, 183, C1426AVC, Ciudad de Buenos Aires, Argentina

2 Programa de Estudios de Procesos Atmosféricos en el Cambio Global - PEPACG, Consejo Nacional de Investigaciones Científicas y Técnicas - CONICET,

Universidad Carólica Argentina - UCA

${ }^{3}$ Consejo Nacional de Investigaciones Científicas y Técnicas - CONICET, Av. Rivadavia, 1917, C1033AAJ, Buenos Aires, Argentina, E-mail: zamoramariacl@gmail.com

${ }^{*}$ A quem a correspondência deve ser enviada 
Table 1. Mean ${ }^{*}$ daily environmental temperatures for April $29^{\text {th }}, 30^{\text {th }}$, and May $1^{\text {st }}$ in selected Mexican cities.

\begin{tabular}{|c|c|c|c|c|c|c|}
\hline \multirow[t]{2}{*}{ Place } & \multirow[t]{2}{*}{ Latitude } & \multirow[t]{2}{*}{ Longitude } & \multirow[t]{2}{*}{ Altitude (m) } & \multicolumn{3}{|c|}{ Mean temperature ${ }^{\star}\left({ }^{\circ} \mathrm{C}\right)$} \\
\hline & & & & April 29 & April 30 & May 1 \\
\hline Mérida & $20^{\circ} 56^{\prime} 47^{\prime \prime}$ & $89^{\circ} 39^{\prime} 06^{\prime \prime}$ & 18 & 30.7 & 29.6 & 27.9 \\
\hline Paraíso & $18^{\circ} 25^{\prime} 24^{\prime \prime}$ & $93^{\circ} 09^{\prime} 20^{\prime \prime}$ & 4 & 30.5 & 29.0 & 27.9 \\
\hline Pinotepa & $16^{\circ} 20^{\prime} 59^{\prime \prime}$ & $93^{\circ} 09^{\prime} 20^{\prime \prime}$ & 195 & 28.6 & 28.8 & 28.9 \\
\hline
\end{tabular}

${ }^{\star}$ Calculated from hourly temperature measurements of the day.

Paraíso, and Pinotepa as well as their mean daily environmental temperatures along three consecutive days, namely April $29^{\text {th }}$, $30^{\text {th }}$, and May $1^{\text {st }}, 2006$. The average temperature values for January ranged between $24-27^{\circ} \mathrm{C}$ for all different places.

The hourly surface temperature records (24 measurements/ day) for each day were also obtained and the corresponding temperature profiles in the selected cities are shown in Figure 1.

For the purposes of the present work, we considered that the cooked meat food was prepared (and contaminated) early in the morning (e.g. 8:00 am) and then stored at ambient temperature during diurnal time before selling/consumption. As shown by the temperature profiles (Figure 1), at 8:00 am the temperature is about $25^{\circ} \mathrm{C}$ in all locations. It increases slowly and remains at about $35-40^{\circ} \mathrm{C}$ for several hours, and then it begins to decline.

\section{Growth kinetics of Staphylococcus aureus in a cooked meat product stored at constant temperatures}

ICMSF (1996) reported the generation time, GT (also called doubling time) and lag phase duration of S. aureus inoculated ( 3 log counts/g) in a pasteurized beef and kidney pie, having pH 5.8 and water activity $\left(\mathrm{a}_{\mathrm{w}}\right) 0.98$, stored at various constant temperatures. During the lag phase, the cells are adjusting to their new environment; during the exponential phase of growth, bacteria multiply by binary fission, and the so-called stationary phase occurs when the bacterial level (S. aureus in this case) reaches a high critical concentration (e.g. around $1 \times 10^{9}$ ). The lag phase time decreases rapidly with temperature increase, but it approached some sort of asymptotic value (180 minutes) at $25-40{ }^{\circ} \mathrm{C}$. The generation time (GT) decreased with increasing temperature, and may be described by the following empirical Equation 1 (between 25 and $43{ }^{\circ} \mathrm{C}$ ),

$\mathrm{GT}=-0,0185 \mathrm{~T}^{3}+2.1314 \mathrm{~T}^{2}-82.205 \mathrm{~T}+1083.5$

where GT is given in minutes and $\mathrm{T}$ is temperature, ${ }^{\circ} \mathrm{C}$.

A simplified approach was used in this study to predict $S$. $a u$ reus growth under changing ambient temperature. It consists in using the well known relationship between the number of bacteria at a given time $\left(\mathrm{N}_{\mathrm{t}}\right)$, the original number of bacterial cells $(\mathrm{No})$, the generation time (GT), and time ( $\mathrm{t}$ ) (Equation 2),

$\mathrm{N}_{\mathrm{t}}=\mathrm{N}_{\mathrm{o}} \cdot 2^{\mathrm{t} / \mathrm{GT}}$

where $t$ is time elapsed after the lag phase completed. According to this study's predictions for cooked meat, $\mathrm{N}_{\mathrm{o}}$ is taken as 3
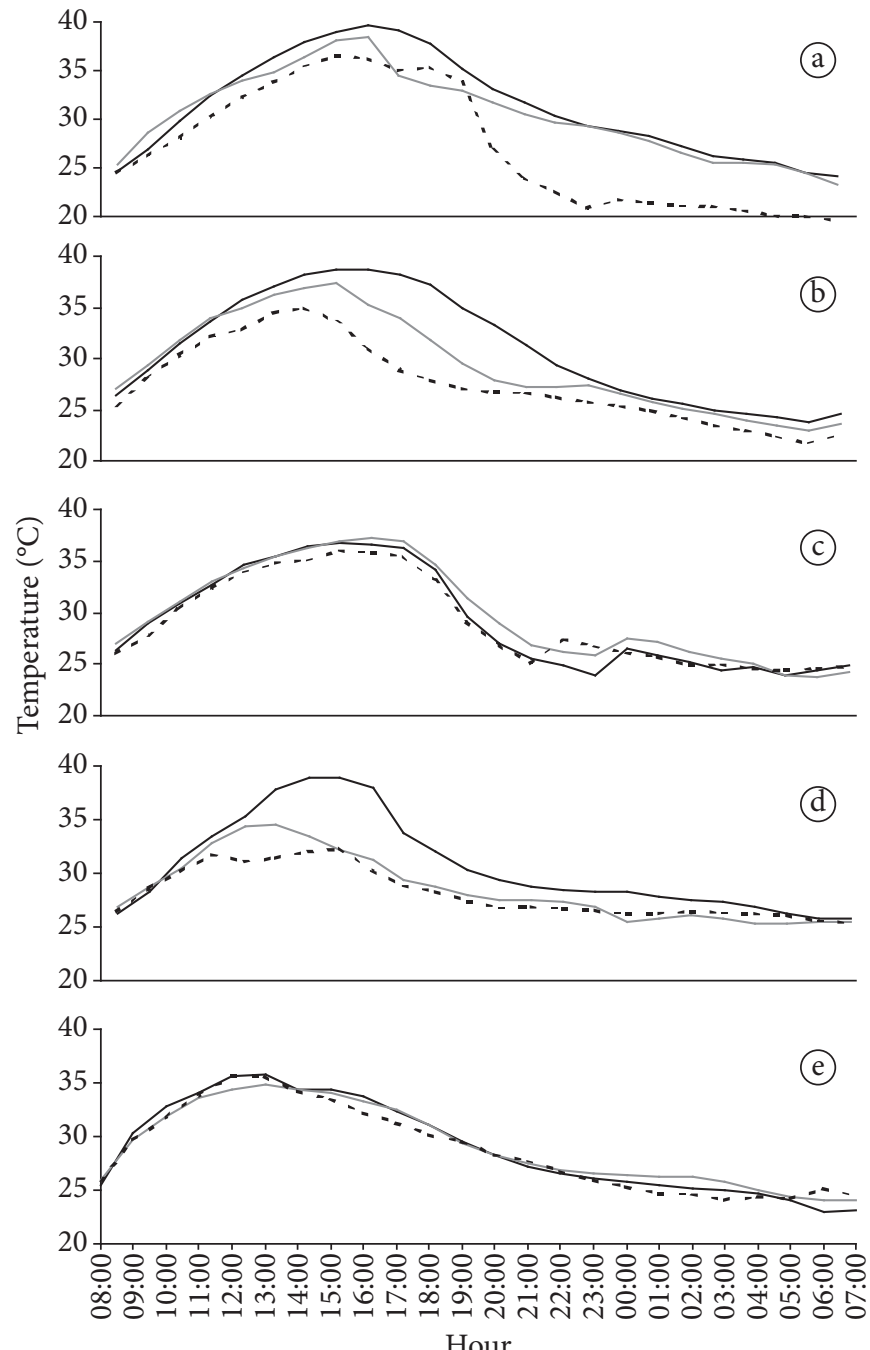

Hour

April $29^{\text {th }}-\quad$ April $30^{\text {th }}-\quad$ May $1^{\text {st }} \ldots$

Figure 1. Hourly environmental temperaturas, in selected Mexican cities. a) Iguala; b) Mérida, c) Palenque; d) Paraíso; and e) Pinotepa.

$\log$ counts/g (inocula value) and the lag phase time is known (180 minutes). The use of Equation (2) is valid only for predictions in the exponential growth phase of the bacterial curve. In the present work, the maximum predicted value of $S$. aureus counts 
in the cooked meat product is limited to $\mathrm{N}_{\mathrm{t}}=1 \times 10^{6} \mathrm{CFU}_{\mathrm{g}} \mathrm{g}^{-1}$, a value within the exponential growth phase.

It was assumed that the cooked food was prepared (and contaminated) at 8:00 am since the ambient temperature in all locations that morning time was close to $25^{\circ} \mathrm{C}$ (Figure 1). The lag phase time was considered 180 minutes.

Subsequent growth of $S$. aureus exposed to the daily changing ambient temperatures in every selected city was calculated (Equation 2) by the accumulated sum of the various one-hour intervals in the time interval considered. For each interval, generation time was evaluated (Equation 1) at the middle point temperature of every one-hour interval. Calculations ended by the time the staphylococcal population $\left(\mathrm{N}_{\mathrm{t}}\right)$ reached $1 \times 10^{6} \mathrm{CFU}_{\mathrm{g}}{ }^{-1}$, which is a count number likely to be associated with enterotoxin production. The number of staphylococci required to cause an illness cannot be predicted with certainty because many variables affect the amount of enterotoxin produced in a contaminated food. Stewart et al. (2003) cited that according to a 1992 guideline given by the U.S. Food and Drug Administration, the effective dose of enterotoxin may be achieved when the population of $S$. aureus reaches a level of $>10^{5}$ colony forming units CFU.g ${ }^{-1}$. Niskanen and Nurmi (1976) reported that contaminations of $S$. aureus over $2 \times 10^{6} \mathrm{CFU} . \mathrm{g}^{-1}$ were associated with enterotoxin production in dry sausage.

\section{Results and discussion}

A great concern for predictive microbiology is predicting bacterial growth under changing temperature conditions (ZWIETERING et al., 1994) because depending on the magnitude of the temperature deviation, the organism may change its rate of growth to a characteristic rate of the new temperature, or it may stop growing if a lag phase is introduced.

Langeveld and Cuperus (1980) found that bacteria within the exponential phase respond immediately to a change in temperature and Zwietering et al. (1994) also indicated that shifts during the exponential phase in a moderate temperature range results in immediate exponential growth at the growth rate associated with the new temperature. However, shifts to or from low temperatures resulted in an adaptation period.

This study's predictions considered that $S$. aureus cells contaminating the cooked meat adapt continuously to a new growth rate characteristic of the new temperature when exposed to the changing environmental (ambient) temperature during selected diurnal times. This assumption is based in two important facts: 1) the changing environmental temperature occurs in a range which is close to the optimum for $S$. aureus growth $\left(25-40{ }^{\circ} \mathrm{C}\right)$, and b) the highest average rate of diurnal temperature change is low, about $2^{\circ} \mathrm{C} /$ hour (Figure 1). These factors mean that a "heat shock" (which may affect bacterial cells) never occurred.

Table 2 shows the calculated time for a 3-fold log increase (from inocula of $10^{3} \mathrm{CFU}_{\mathrm{g}^{-1}}$ ) of $\mathrm{S}$. aureus count in cooked beef and kidney pie using two different ambient temperature approaches (for each of the five locations considered): a) hourly temperatures at a specified diurnal period of the selected days; and b) mean daily temperature of the selected days.

Time for a 3 -fold log (including the 3 hours lag time) counts ranged between 6.8 to 8.1 hours for the different locations/days when the bacterial growth was calculated by the accumulated sum of various one-hour intervals in the time interval considered. This means that if a food is prepared (and contaminated) at 8:00 a.m. and kept at ambient temperature (i.e. street vendor), it will reach $10^{6}$ CFU.g ${ }^{-1}$ (value usually associated with the presence of toxin) at about 3:00-4:00 pm. It is noteworthy that growth times predicted using the daily mean ambient temperature (value which is generally more available) overestimate the time for $S$. aureus growth if compared with those calculated using the actual (changing) ambient temperature. This is due to the effect of night cooling. The results obtained agreed with those recently reported by us (BAEZA et al., 2007) for S. aureus growth for the same kind of cooked meat product but exposed to temperature profiles corresponding to several cities of Argentina during summer time.

\section{Conclusions}

It can be concluded that mean daily ambient temperatures - although usually easily more available- may not adequately model bacterial response when a contaminated food is kept at "ambient" conditions for several hours during diurnal time (i.e. temperature abuse). The findings are also useful to estimate the time needed for $S$. aureus to grow to dangerous levels when a contaminated food is kept at ambient temperature in warm climates (i.e. the case of street vendors).

Table 2. Time for a 3-fold log increase (including lagtime) from inocula of $10^{3} \mathrm{CFU} \cdot \mathrm{g}^{-1}$ of $S$. aureus count in ground beef and kidney pie: calculations using different environmental temperature approaches.

\begin{tabular}{|c|c|c|c|c|c|c|}
\hline \multirow[t]{3}{*}{ Location } & \multicolumn{6}{|c|}{ Time for a 3-fold log increase (from $10^{3} \mathrm{CFU}^{-1}{ }^{-1}$ ) (hour) } \\
\hline & \multicolumn{2}{|c|}{ April $29^{\text {th }}, 2006$} & \multicolumn{2}{|c|}{ April $30^{\text {th }}, 2006$} & \multicolumn{2}{|c|}{ May $1^{\text {st }}, 2006$} \\
\hline & $\begin{array}{c}\text { Using specified } \\
\text { hourly temperatures }\end{array}$ & $\begin{array}{l}\text { Using mean } \\
\text { temperature }\end{array}$ & $\begin{array}{c}\text { Using specified } \\
\text { hourly temperatures }\end{array}$ & $\begin{array}{l}\text { Using mean } \\
\text { temperature }\end{array}$ & $\begin{array}{c}\text { Using specified } \\
\text { hourly temperatures }\end{array}$ & $\begin{array}{l}\text { Using mean } \\
\text { temperature }\end{array}$ \\
\hline Iguala & 6.9 & 8.4 & 7.0 & 8.7 & 7.3 & 10.1 \\
\hline Mérida & 6.8 & 8.5 & 6.9 & 9.3 & 7.3 & 10.9 \\
\hline Palenque & 7.0 & 9.3 & 7.1 & 9.7 & 7.1 & 9.6 \\
\hline Paraíso & 6.8 & 8.7 & 7.3 & 9.8 & 8.1 & 10.8 \\
\hline Pinotepa & 7.0 & 10.1 & 7.1 & 10.0 & 7.1 & 9.9 \\
\hline
\end{tabular}




\section{Acknowledgements}

The authors acknowledge the support of Dr. Pablo Canziani from PEPACG, UCA-CONICET.

\section{References}

BAEZA, R. et al. Simplified prediction of Staphylococcus aureus growth in a cooked meat product exposed to changing environmental temperatures in warm climates. Revista Argentina de Microbiología, v. 39, n. 4, p. 237-242, 2007.

CABALLERO TORRES, A.; CARRERA VARA, J. A.; LENGOMÍN FERNÁNDEZ, M. E. Evaluation of the microbiological surveillance of street vended foods. Revista Cubana de Alimentacion y Nutricion, v. 12, n. 1, p. 7-10, 1998.

ICMSF. International Commission on Microbiological Specification for Food. Microorganismos de los alimentos. Características de los patógenos microbianos. España: E. Acribia S.A., 1996. p. 358-59.

LANGEVELD, L. P. M.; CUPERUS, F. The relation between temperature and growth rate in pasteurized milk of different types of bacteria which are important to the deterioration of that milk. Netherlands Milk and Dairy Journal, v. 34, p. 106-125, 1980.

MENSAH, P. et al. Street foods in Accra, Ghana: how safe are they? Bulletin of the World Health Organization, v. 80, n. 7, p. 546-554, 2002.

NISKANEN, A.; NURMI, E. Effect of starter culture on staphylococcal enterotoxin and thermonuclease production in dry sausage. Applied and Environmental Microbiology, v. 31, n. 1, p. 11-20, 1976.

STEWART, C. M.; COLE, M. B.; SCHAFFNER, D. W. Managing the risk of staphylococcal food poisoning from cream- filled baked goods to meet a food safety objective. Journal of Food Protection, v. 66, n. 7, p. 1310-25, 2003.

WALLS, I.; SCOTT, V. N. Use of predictive microbiology in microbial food safety risk assessment. International Journal of Food Microbiology, v. 36, n. 2-3, p. 97-102, 1997.

ZWIETERING, M. H. et al. Modelling of bacterial growth with shifts in temperature. Applied and Environmental Microbiology, v. 60, n. 1, p. 204-13, 1994. 